\title{
PERKEMBANGAN PEMIKIRAN DAN PERGERAKAN WANITA DALAM PANDANGAN FEMINIS MUSLIM
}

\author{
Asfa Fikriah \\ Lalu Iwan Eko Jakandar \\ Sekolah Tinggi Ilmu Tarbiyah Islamiyah NTB
}

\begin{abstract}
Islam is the religion of rahmatan lil-'alamin which carries the main mission to realize the benefits and justice for humanity and all beings in the world. Islam provides rules that are fair to humans, especially for men and women, so that everyone benefits from the rules. With two main sources, the Qur'an and the Sunnah, Islam places men and women fairly and equally, even though there are different rules for both. However, the ulama's interpretation of the Qur'an and Sunnah based on culture led to the emergence of the determination (figh) of the women lost from the mission carried out by two sources. The emergence of feminist Muslim leaders with ideas of gender equality has a significant effect on the Muslim community to realize the injustices of men and women over the years, especially in Islam, and try to return to justice and gender equality.
\end{abstract}

Kata Kunci: Women, justice, equality, gender, Muslim feminists. 


\section{A. Pendahuluan}

Islam adalah agama yang membawa misi besar, yakni rahmatan lil 'alamin (rahmat bagi seluruh alam semesta). Untuk menyebarkan rahmat bagi semua ini, Islam juga membawa misi utama untuk terwujudnya kemaslahatan, keadilan, dan kebebasan. Semua aturan Islam, terutama yang tertuang dalam Al-Qur'an menjadi bukti akan hal tersebut. Kalaupun kemudian muncul banyak penafsiran yang menyimpang dari misi-misi tersebut, hal ini karena adanya penafsiran terhadap Al-Qur'an yang didasari oleh konteks sosial budaya yang melingkupi para penafsirnya, atau juga karena pemahaman yang literal terhadap teks-teks hadis Nabi Muhammad Saw.

Dalam memaknai ayat-ayat Al-Qur'an yang secara umum membawa pesan keadilan, para penafsir terkadang mengambil keputusan yang berbeda hanya karena adanya ayat yang bisa diarahkan sesuai dengan penafsirannya dan juga karena didukung oleh budaya patrilineal yang kental di kalangan masyarakat Muslim. Adanya hadis-hadis Nabi yang misoginis (merendahkan perempuan) lebih memperkuat keyakinan penafsir untuk memegangi pendapatnya. $\mathrm{Di}$ sinilah muncul tafsir-tafsir yang banyak memposisikan perempuan dalam posisi yang inferior.

Dalam kurun waktu berabad-abad lamanya, penafsiran yang merendahkan perempuan mendominasi opini dan keyakinan umat Islam di belahan bumi ini. Munculnya feminisme di Barat memberikan inspirasi yang sangat berharga kepada sebagian kecil umat Islam (para penafsir) akan pentingnya melakukan reinterpretasi dan reformulasi fikih (pemahaman hukum) perempuan. Dengan mendasarkan kepada ayat-ayat $\mathrm{Al}$-Qur'an yang membawa misi keadilan, persamaan, dan kesetaraan, mereka berusaha mencari akar masalah mengapa muncul penafsiran yang tidak adil dalam memberikan status terhadap laki-laki dan perempuan (gender). Mereka melakukan penelusuran terhadap hadis-hadis yang menjadi "biang" terjadinya ketidakadilan tersebut dan menfsirkan dengan melihat konteks (asbabul wurud) hadis 
tersebut. Mereka inilah yang dikenal dengan kaum feminis Muslim.

Tulisan ini akan mengungkap sedikit dari tokoh-tokoh feminis Muslim yang memberikan sumbangan berarti dalam perekembangan pemikiran Islam, khususnya yang terkait dengan perspektif gender. Kebanyakan dari mereka adalah kaum perempuan Muslimah, dan sebagian yang lain adalah kaum laki-laki. Sebelum menguraikan para tokoh feminis Muslim serta pemikiran mereka, akan dikemukakan terlebih dahulu kedudukan perempuan dalam Islam.

\section{B. Pembahasan}

\section{Kedudukan Perempuan dalam Hukum Islam}

Islam menempatkan kedudukan perempuan pada proporsinya dengan mengakui kemanusiaan perempuan dan mengikis habis kegelapan yang dialami perempuan sepanjang sejarah serta menjamin hak-hak perempuan. Untuk menjelaskan kedudukan perempuan dalam hukum Islam, dasar hukum yang harus dipegangi adalah kedua sumber utama hukum Islam, yaitu Al-Qur'an dan Sunnah (hadis). Dari dua sumber inilah diperoleh prinsip-prinsip yang pasti untuk melihat kedudukan perempuan dalam Islam. Namun, harus dimaklumi bahwa prinsip-prinsip yang sudah digariskan oleh Al-Qur'an dan Sunnah terkadang dipraktikkan berbeda oleh umat Islam dalam kehidupan sehari-hari. Bahkan harus disadari pula bahwa ayat-ayat Al-Qur'an dan hadis-hadis Nabi Saw. yang sebenarnya menyuarakan masalah keadilan dan persamaan sering dipahami yang sebaliknya, sehingga di kalangan pemikir Islam (ulama) timbul perbedaan pendapat dalam berbagai permasalahan Islam, termasuk hukum Islam. Dalam posisi seperti ini, Al-Qur'an memberikan solusi yang tegas, bahwa jika di antara kita terjadi perbedaan pendapat maka seharusnya kita kembali merujuk kepada Allah dan Rasulullah untuk memutuskan perkaranya (QS. al-Nisa' [4]: 59). Karena itu, ketika dalam masyarakat Islam berkembang opini yang berbeda-beda mengenai hak dan kewajiban perempuan, misalnya, maka kita harus kembali merujuk kepada

190 Perkembangan Pemikiran dan Pergerakan Wanita.... 
ketentuan-ketentuan yang ada dalam Al-Qur'an dan Sunnah Nabi Muhammad Saw.

Al-Qur'an diwahyukan untuk segenap manusia, untuk sepanjang masa, dan untuk seluruh tempat. Karena itu Al-Qur'an selalu relevan bagi siapa pun, di mana pun, dan kapan pun. Al-Qur'an dengan tegas menyebutkan bahwa kaum laki-laki dan kaum perempuan diciptakan dari nafs (jiwa) yang sama, dan bahwa orang laki-laki dan perempuan Muslim adalah masing-masing sebagai pelindung dan sahabat bagi yang lainnya. Keduanya juga memiliki tugas yang sama dan kesempatan untuk memeroleh rahmat dari Allah (QS. alTaubah [9]: 71).

Kenyataannya sekarang ini masih banyak kaum perempuan Muslimah yang mengingkari hak-hak asasinya dengan mengatasnamakan Islam. Para suami telah menyalahgunakan kenyataan ini dengan mengingkari seruan-seruan Al-Qur'an yang menegaskan bahwa hubungan antara suami dan isteri adalah hubungan yang penuh rahmat dan kasih sayang (QS. al-Rum [30]: 21). Kaum perempuan mengingkari hak-hak mereka untuk mendapatkan pendidikan, memeroleh pekerjaan, dan memasuki dunia publik juga atas nama Islam. Beberapa di antara kaum Muslim bahkan menolak keanekaragaman dengan menunjukkan sikap-sikap yang rasial dan sexist. ${ }^{1}$

Al-Qur'an selalu menekankan logika yang berasal dari Allah, ketika berulang-ulang menyebutkan bahwa laki-laki dan perempuan diciptakan dari nafs yang sama (QS. alNisa' [4]: 1, al-An'am [6]: 98, al-A'raf (7): 189, Luqmān (31): 28, dan al-Zumar (39): 6). Dalam AlQur'an tidak terdapat satu penjelasan sedikit pun seperti dalam kitabkitab suci lainnya bahwa perempuan diciptakan dari suatu bahan

1 Al-Hibri, Azizah. "Landasan Qur'ani Mengenai Hak-hak Perempuan Muslim pada Abad Ke-21", dalam Mohammad Atho Mudzhar dkk. (Ed.). Perempuan dalam Masyarakat Indonesia: Akses, Pemberdayaan dan Kesempatan. (Yogyakarta: Sunan Kalijaga Press). 2001. hlm. 6 
yang lebih rendah dari bahan untuk laki-laki, bahwa status perempuan adalah parasit dan rendah, atau bahwa Hawa diciptakan dari salah satu tulang rusuk kiri Adam. Di samping itu, dalam Al-Qur'an tidak ada satu pandangan pun yang meremehkan perempuan berkenaan dengan watak dan struktur bawaannya. Al-Qur'an membersihkan perempuan dari tuduhan sebagai sumber godaan dan dosa seperti yang dijelaskan dalam kitab-kitab suci lainnya. ${ }^{2}$

Namun demikian, masih banyak di antara para ahli hukum (fuqaha) yang membatasi persamaan antara kedudukan laki-laki dan perempuan hanya sampai pada batas persamaan secara spiritual saja dan membiarkan masyarakat mereka membuat hierarki-hierarki dan pembatasan-pembatasan berdasarkan gender. Beberapa negara Islam telah memberlakukan pembatasan-pembatasan terhadap kaum perempuan untuk hal-hal tertentu. Afghanistan, misalnya, telah memberlakukan larangan bagi perempuan untuk mendapatkan pendidikan dengan mengatasnamakan Islam. ${ }^{3}$ Di sebagian negara Timur Tengah, misalnya Saudi Arabia, kaum perempuan masih belum diberikan hak politik yang sepenuhnya, bahkan belum memiliki hak untuk menentukan pilihan dalam pemilihan kepala negara atau kepala pemerintahan. ${ }^{4}$

Ayat Al-Qur'an yang dengan tegas melihat kesejajaran kaum perempuan dengan kaum laki-laki adalah QS. al-Lail (92): 3-10 yang menyebut kaum laki-laki dan perempuan dalam qasam (sumpah) yang merupakan bukti (qarinah) bahwa Allah melihat persamaan antara keduanya. Ayat-ayat tersebut mengisyaratkan bahwa

2 Mutahhari, Murteza. Perempuan dan Hak-haknya dalam Islam. Alih bahasa oleh M. Hashem dari “The Rights of Women in Islam”. (Bandung: Pustaka). Cet. I. 1985. hlm. 96-97

3 Al-Hibri, Azizah. "Landasan Qur'ani Mengenai Hak-hak Perempuan Muslim pada Abad Ke-21", dalam Mohammad Atho Mudzhar dkk. (Ed.). Perempuan dalam Masyarakat Indonesia: Akses, Pemberdayaan dan Kesempatan. (Yogyakarta: Sunan Kalijaga Press). 2001. hlm. 19

4 El-Saadawi, Nawal. Wajah Telanjang Perempuan. Alih bahasa oleh Azhariah dari "Al-Wajhu al-'Ari li al-Mar'ah al-'Arabiyyah.” Yogyakarta: Pustaka Pelajar. Cet. I. 2003, hlm. 181-184 
perbedaan manusia hanya terletak pada aksinya, apakah baik atau buruk, dengan tidak melihat jenis kelaminnya. Ayat tersebut juga merupakan deklarasi Al-Qur'an pertama terhadap prinsip taklif baik laki-laki maupun perempuan dalam persoalan dunia dan agama; juga merupakan prinsip balasan bagi usaha dari laki-laki dan perempuan berdasarkan aktivitas kerja mereka; dan merupakan pendeklarasian persamaan antara laki-laki dan perempuan dalam kecenderungan untuk melakukan aktivitas. ${ }^{5}$

Studi yang dilakukan Nasaruddin Umar terhadap Al-Qur'an menunjukkan adanya kesetaraan gender. Dia menemukan lima variabel yang mendukung pendapatnya, yakni: 1) Laki-laki dan perempuan sama-sama sebagai hamba. Hal ini bisa dilihat misalnya dalam QS. al-Hujurat (49): 13 dan al-Nahl (16): 97; 2) Laki-laki dan perempuan sebagai khalifah di bumi. Hal ini terlihat dalam QS. al-Baqarah (2): 30 dan al-An'am (6): 165; 3) Laki-laki dan perempuan menerima perjanjian primordial seperti terlihat dalam QS. alA'raf (7): 172; 4) Adam dan Hawa terlibat secara aktif dalam drama kosmis. Kejelasan ini terlihat dalam QS. al-Baqarah (2): 35 dan 187, al-A'raf (7): 20, 22, dan 23; dan 5) Laki-laki dan perempuan berpotensi meraih prestasi seperti yang terlihat dalam QS. Ali 'Imran (3): 195, al-Nisa' (4): 124, al-Nahl (16): 97, dan al-Mu'min (40): $40 .^{6}$

Kalaupun kemudian muncul pendapat yang bernada misoginis terhadap perempuan, atau yang menunjukkan subordinasi perempuan dan superioritas laki-laki, dikarenakan adanya bias gender dalam pemahaman atau penafsiran teks-teks Al-Qur'an. Persoalan yang sama seperti itu juga terjadi dalam pemahaman terhadap teks-teks hadis. Namun, dalam bidang hadis ini juga dipengaruhi oleh status atau kualitas hadis yang oleh para ulama hadis dinilai berbeda-beda. Memang keberadaan hadis tidak seperti Al-Qur' an yang sejak turunnya

5 Shalih, Su'ad. Ibrahim. "Kedudukan Perempuan dalam Islam”, dalam Mohammad Atho Mudzhar dkk. (Ed.). Perempuan dalam Masyarakat Indonesia: Akses, Pemberdayaan dan Kesempatan. (Yogyakarta: Sunan Kalijaga Press). 2001, hlm. 40

6 Umar, Nasaruddin. Argumen Kesetaraan Jender: Perspektif Al-Qur'an. Jakarta: Paramadina. Cet. I. 1999, hlm. 248-269 
hingga sekarang tidak diragukan keautentikannya. Hadis tidak seperti Al-Qur'an, karena sampainya hadis kepada kita sangat sarat dengan peristiwa-peristiwa historis yang bermuatan sosio-kultural, terutama bagi para perawi atau sanad yang membawanya kepada kita. Dari sinilah perlu dilakukan kontekstualisasi pemahaman hadis, yaitu usaha penyesuaian dengan dan/dari hadis untuk mendapatkan pandangan yang sejati, orisinal, dan memadai bagi perkembangan atau kenyataan yang dihadapi. Ini berarti bahwa kontekstualisasi tidak dilakukan untuk menyesuaikan perkembangan dengan teks hadis atau sebaliknya, tetapi kontekstualisasi dilakukan dengan dialog atau saling mengisi di antara keduanya.

Tidak berhenti sampai di situ saja, untuk memosisikan perempuan dalam posisi yang sebenarnya-sebagaimanayang ditegaskan oleh Al-Qur'an - maka perlu dilakukan kajian ulang terhadap hadishadis yang misoginis, yakni hadis-hadis yang isinya merendahkan perempuan, sehingga memperlihatkan adanya ketimpangan gender antara laki-laki dan perempuan. ${ }^{7}$ Kritik terhadap hadis-hadis yang misoginis tidak hanya dalam hal sanadnya, tetapi juga dalam hal matannya. Jika ditelusuri hadis-hadis yang misoginis tersebut, ternyata sebagiannya adalah hadis-hadis yang shahih. Sebagai contoh adalah hadis yang diriwayatkan oleh al-Bukhari yang isinya bahwa kebanyakan perempuan adalah penghuni neraka dan hadis yang menegaskan tentang ketidakberhasilan suatu negara yang dipimpin oleh perempuan. Terhadap hadishadis shahih seperti itu, yang harus dilakukan adalah mengkritisinya melalui jalur matan, yakni dengan mengkaji ulang makna yang ada di balik bunyi teks hadis tersebut dan menyesuaikannya dengan konteks (asbabulwurud) yang terjadi di saat teks itu muncul.

Untuk melengkapi uraian tentang kedudukan perempuan dalam hukum Islam, selanjutnya akan dijelaskan beberapa pemikiran para tokoh Islam yang digolongkan ke dalam kelompok feminis Muslim

7 Fudhaili, Ahmad. (2005). Perempuan di Lembaran Suci: Kritik atas Hadis-hadis Sahih. Yogyakarta: Pilar Religia. Cet. I. 2005, hlm. xi

194 Perkembangan Pemikiran dan Pergerakan Wanita.... 
terkait dengan relasi antara laki-laki dan perempuan (relasi gender) dalam berbagai bidang kehidupan mereka. Pemikiran hukum Islam dari para feminis Muslim ini bisa disebut juga sebagai pemikiran hukum Islam yang berperspektif gender. Artinya pemikiran ini tidak menunjukkan adanya dominasi salah satu jenis kelamin (seperti laki-laki) atas jenis kelamin lainnya (yakni perempuan), sehingga akan memunculkan ketidakadilan gender dalam relasi laki-laki dan perempuan.

\section{Tokoh-tokoh Feminis Muslim}

Para pemikir feminis Muslim yang berusaha melakukan dekonstruksi terhadap pemahaman para ulama mengenai perempuan yang menempatkan perempuan pada posisi yang inferior dan laki-laki pada posisi yang superior. Oleh karena itu, penulis akan mencoba menampilkan pemikiran dari beberapa tokoh feminis Muslim yang mencoba melakukan dekontruksi pemahaman mengenai status perempuan dalam Islam. Penulis hanya akan menampilkan lima tokoh feminis Muslim yang pemikirannya penulis anggap mewakili para tokoh feminis Muslim lainnya dan menjadi acuan para feminis Muslim dalam melakukan kajian-kajian Islam yang berperspektif gender. Para tokoh yang penulis maksudkan adalah Qasim Amin dari Mesir, Amina Wadud Muhsin dari Malaysia (sekarang di Amerika Serikat), Fatima Mernissi dari Maroko, dan Asghar Ali Engineer dari India. Di bawah ini akan penulis uraikan secara berurutan keempat tokoh ini beserta pemikiran mereka mengenai kedudukan perempuan dalam Islam.

\section{Qasim Amin}

Qasim Amin adalah tokoh feminis Muslim pertama yang dilahirkan di Tarah, Iskandariah (Mesir), Desember 1865. Qasim dapat menyelesaikan pendidikan tingginya dalam waktu yang relatif singkat. Di antara guru yang dikaguminya di Al-Azhar adalah Muhammad Abduh. Pola berpikir kritis banyak diperolehnya dari guru favoritnya 
itu. Karena kecerdasannya, Qasim Amin kemudian mendapat kesempatan untuk melanjutkan studi ke Fakultas Hukum Universitas Montpellier di Paris Perancis. Sekembalinya ke Mesir, Qasim Amin bekerja pada Dewan Perwakilan Rakyat dan pada sebuah lembaga hukum. Ia menetap di Kairo hingga wafatnya 22 April 1908. Di antara karya-karyanya yang banyak menggugah semangat perempuan untuk bangkit adalah Tahrir al-Mar'ah (1900) dan al-Mar'ah al-Jadidah (1911). Dua karya inilah yang kemudian banyak memberi inspirasi kepada para feminis Muslim untuk memperjuangkan kebebasan untuk perempuan setelahnya hingga sekarang. ${ }^{8}$ Qasim Amin adalah salah satu tokoh feminis Muslim yang pertama kali memunculkan gagasan tentang emansipasi perempuan Muslim melalui karya-karyanya. Qasim Amin memunculkan gagasannya didasari oleh keterbelakangan umat Islam yang menurutnya disebabkan salah satunya oleh persepsi dan perlakuan yang salah terhadap perempuan. ${ }^{9}$

Gagasan Qasim Amin tentang emansipasi menyulut kontroversi diskursus di kalangan ulama Mesir pada waktu itu. Meskipun ide Qasim Amin ini mendapat banyak sorotan dari para ulama AlAzhar, ia tidak pernah surut untuk menyuarakannya. Ide emansipasi bertujuan untuk membebaskan kaum perempuan sehingga mereka memiliki keleluasaan dalam berpikir, berkehendak, dan beraktivitas sebatas yang dibenarkan oleh ajaran Islam dan mampu memelihara standar moral masyarakat. Kebebasan dapat menggiring manusia untuk maju dan bergerak pada kebahagiaan. Tidak seorang pun dapat menyerahkan kehendaknya kepada orang lain, kecuali dalam keadaan sakit jiwa dan masih anak-anak. ${ }^{10}$ Karena itulah ia menyarankan adanya perubahan, karena menurutnya tanpa perubahan mustahil kemajuan dapat dicapai.

8 Sukri, Sri Suhandjati (Ed.). Bias Jender dalam Pemahaman Islam. Yogyakarta: Gama Media. Cet. I. 2002, hlm. 194-195

9 Nasution, Harun. Pembaharuan dalam Islam: Sejarah, Pemikiran, dan Gerakan. Jakarta: Bulan Bintang. Cet. VIII. 1991, hlm. 79

10 Amin, Qasim. Tahrir al-Mar'ah. Kairo: Al-Markaz al-'Arabiyyah li al-Bahtsi wa al-Nasyr. 1984, hlm. 49

196 Perkembangan Pemikiran dan Pergerakan Wanita.... 
Menurut Qasim Amin, syari'ah menempatkan perempuan sederajat dengan lakilaki dalam hal tanggung jawabnya di muka bumi dan di kehidupan selanjutnya. Jika perempuan melakukan tindak kriminal, bagaimana pun juga, hukum tidak begitu saja membebaskannya atau merekomendasikan pengurangan hukuman padanya. Qasim meyakini, tidaklah masuk akal menganggap perempuan memiliki rasionalitas yang sempurna, bebas, dan berhak mendapat hukuman jika ia melakukan pembunuhan, sementara di saat yang sama tidak ada tanggapan apa pun atas perempuan ketika kebebasannya dirampas. ${ }^{11}$

Kebebasan umum bahwa kebebasan kaum perempuan akan membahayakan kesucian mereka, menurut Qasim Amin, tidak berdasarkan pada kenyataan yang kuat.

Pengalaman mengindikasikan bahwa kebebasan perempuan bisa menambah pengertian akan tanggung jawab dan kehormatan dirinya, dan mendorong orang-orang untuk menghormatinya. Untuk memperkuat analisisnya, Qasim Amin menyajikan data statistik bahwa kaum perempuan di Barat (Jerman, Belgia, Perancis, dan Belanda) banyak memperdaya suami mereka. ${ }^{12}$

Di samping menganjurkan kebebasan bagi perempuan, Qasim Amin juga mengecam tradisi pemingitan terhadap perempuan pada waktu itu. Agar kaum perempuan tidak mengalami pemingitan, maka, menurut Qasim Amin, mereka harus mendapatkan pendidikan yang memadai seperti halnya laki-laki. Ia kurang setuju jika perempuan diberikan pendidikan yang khusus yang berbeda dengan pendidikan yang diberikan kepada laki-laki. ${ }^{13}$

Itulah pemikiran Qasim Amin tentang kebebasan perempuan yang cukup kontroversial pada waktu itu, terutama bagi kalangan

11 Amin, Qasim. Tahrir al-Mar'ah. Kairo: Al-Markaz al-'Arabiyyah li al-Bahtsi wa al-Nasyr. 1984, hlm. 65

12 Amin, Qasim. Tahrir al-Mar'ah. Kairo: Al-Markaz al-'Arabiyyah li al-Bahtsi wa al-Nasyr. 1984, hlm. 66

13 Amin, Qasim. Tahrir al-Mar'ah. Kairo: Al-Markaz al-'Arabiyyah li al-Bahtsi wa al-Nasyr. 1984, hlm.147-148 
ulama Al-Azhar (Mesir). Dia mendapat serangan yang bertubi-tubi dari para ulama atas ide-idenya itu. Namun ia tetap tegar dan terus menyuarakan ide-idenya yang menurutnya tidak bertentangan dengan syariah. Justeru memingit perempuan di rumah dan membatasi ruang geraknya bertentangan dengan syariah yang mensejajarkan dua jenis kelamin itu dalam berbuat dan bertanggung jawab.

\section{Amina Wadud Muhsin}

Amina Wadud Muhsin adalah salah satu pemikir feminis kelahiran Malaysia. Dia menamatkan studinya dari pendidikan dasar hingga perguruan tinggi di Malaysia. Dia menamatkan sarjananya dari Universitas Antar Bangsa, masternya dari University of Michigan Amerika Serikat tahun 1989, dan doktornya dari Harvard University tahun

1991-1993. Sekarang ia tinggal di Amerika Serikat menjabat salah satu guru besar di Departemen Filsafat dan Studi Agama pada Universitas Commenwelth di Virginia. Salah satu tulisannya yang kemudian penulis jadikan sebagai bahan kajian terhadap pemikiran feminismenya adalah Qur'an and Woman (1992). Amina pernah membuat geger para ulama dunia, termasuk Syeikh Yusuf al-Qardawi, ketika ia menjadi khathib dan imam shalat Jum'at di New York City tanggal 18 Maret 2005. Belum lama ini juga terbit buku Amina yang berjudul Inside the Gender Jihad: Women's Reform in Islam (2006).

Dalam bukunya Qur'an and Woman, Amina mengawali pembahasannya dengan mengritik penafsiran-penafsiran yang selama ini ada mengenai perempuan dalam Islam. Ia membagi penafsiran tersebut ke dalam tiga kategori, yaitu tradisional, reaktif, dan holistik. Tafsir tradisional, menurut Amina, memberikan interpretasiinterpretasi tertentu sesuai dengan minat dan kemampuan mufassirnya yang bisa bersifat hukum, tasauf, gramatik, retorik, atau historis. Metodologi yang digunakan bersifat atomistik, yaitu penafsiran dilakukan dengan mengupas ayat per ayat secara berurutan. Tidak

198 Perkembangan Pemikiran dan Pergerakan Wanita.... 
ada upaya untuk menempatkan dan mengelompokkan ayat-ayat sejenis ke dalam pokok-pokok bahasan yang tertulis. Yang ditekankan oleh Amina bahwa tafsir-tafsir tradisional itu ditulis oleh kaum laki-laki secara eksklusif. Itulah sebabnya maka hanya laki-laki dan pengalaman laki-laki saja yang direkomendasikan dalam tafsir itu. Sedang perempuan - berikut pengalaman, visi, perspektif, keinginan, atau kebutuhannya - ditundukkan pada pandangan laki-laki. ${ }^{14}$

Kategori kedua adalah tafsir yang isinya terutama mengenai reaksi para pemikir modern terhadap sejumlah besar hambatan yang dialami perempuan yang dianggap berasal dari Al-Qur'an. Persoalan yang dibahas dan metode yang digunakan seringkali berasal dari gagasan kaum feminis dan rasionalis, namun tanpa dibarengi analisis yang komprehensif terhadap Al-Qur'an. Dengan demikian meskipun semangat yang dibawa adalah pembebasan, namun tidak terlihat hubungannya dengan sumber ideologi dan teologi Islam, yaitu AlQur'an. Kategori ketiga adalah tafsir yang menggunakan seluruh metode penafsiran dan mengaitkan dengan berbagai persoalan sosial, moral, ekonomi, dan politik, termasuk isu tentang perempuan pada era modern ini. Menurut Amina, tafsir model ini merupakan metode terbaik. Dalam kategori inilah Amina menempatkan karyanya. ${ }^{15}$

Metode penafsiran yang digunakan Amina adalah metode yang pernah ditawarkan oleh Fazlur Rahman, yaitu metode neomodernis. Rahman berpendapat bahwa ayat-ayat Al-Qur'an yang diturunkan dalam waktu tertentu dalam sejarah - dengan keadaan yang umum dan khusus yang menyertainya - menggunakan ungkapan yang relatif mengenai situasi yang bersangkutan. Oleh karena itu, pesan AlQur'an tidak bisa dibatasi oleh situasi historis pada saat ia diwahyukan saja. Seorang sahabat yang membaca Al-Qur'an harus memahami implikasi-implikasi dari pernyataan-pernyataan Al-Qur'an pada waktu

14 Muhsin, Amina Wadud. Qur'an and Woman. Kuala Lumpur: Fajar Bakti SDN. BHD. Cet. I. 1993, hlm. 1-2

15 Muhsin, Amina Wadud. Qur'an and Woman. Kuala Lumpur: Fajar Bakti SDN. BHD. Cet. I. 1993, hlm.3 
diwahyukan untuk menentukan makna yang dikandungnya. Di sisi lain, generasi Islam selanjutnya, yang situasi dan kondisinya berbeda dengan masa Rasulullah, harus tetap membuat aplikasi praktis dari pernyatan-pernyataan Al-Qur'an yang tetap mempertimbangkan makna utama yang dikandungnya. ${ }^{16}$ Dengan argumen ini, Amina yakin bahwa dalam usaha memelihara relevansinya dengan kehidupan manusia, Al-Qur'an harus terus-menerus ditafsirkan ulang.

Pembahasan Amina mengenai kedudukan perempuan dalam buku tersebut cukup ringkas dan terkesan simpel. Namun, dalam buku tersebut ia menonjolkan semangat egalitarianisme. Ia tidak menganggap matriarkisme adalah alternatif bagi patriarkisme yang selama ini dituding sebagai penyebab ketersudutan perempuan. Ia menginginkan suatu keadilan dan kerja sama antara kedua jenis kelamin tidak hanya pada tataran makro (negara, masyarakat), tetapi juga sampai ke tingkat mikro (keluarga).

\section{Fatima Mernissi}

Fatima Mernissi adalah seorang Muslimah berkebangsaan Maroko. Sekarang ia menduduki jabatan guru besar pada lembaga universiter untuk penelitian ilmiah Universitas Muhammad V Rabat (Maroko). Ia sudah menghasilkan banyak tulisan, baik dalam bentuk buku maupun artikel yang ditulisnya dalam bahasa Perancis. Sebagian karyanya sudah diterbitkan dalam bahasa Inggris dan bahasa Indonesia. Di antara karyannya adalah Beyond the Veil: Male-Female Dynamics in Modern Muslim Society, (1975). Buku ini merupakan desertasinya yang dipertahankan di Brandeis University Amerika Serikat tahun 1973. Bukunya yang lain adalah The Veil and the Male Elite: A

Feminist Interpretation of Women and Islam (1991). Buku lain yang sebenarnya merupakan terjemahan dari buku yang sama adalah Women and Islam: An Historical and Theological Enquiry (1991).

Melalui bukunya The Veil and the Male Elite: A Feminist

16 Muhsin, Amina Wadud. Qur'an and Woman. Kuala Lumpur: Fajar Bakti SDN. BHD. Cet. I. 1993, hlm.7

200 Perkembangan Pemikiran dan Pergerakan Wanita.... 
Interpretation of Women's Rights in Islam, Mernissi mencoba mengupas penyebab ketersudutan perempuan sepeninggal Nabi Muhammad Saw. Melalui buku ini pula, Mernissi mengajak umat Islam untuk melakukan peninjauan ulang terhadap hadis-hadis Nabi yang dinilai menyudutkan perempuan pada posisi yang rendah dan hina. Dia melakukan banyak kritik terhadap hadis Nabi yang dinilainya sudah banyak mengalami penyimpangan dan manipulasi.

Menurut Mernissi, ketersudutan perempuan itu disebabkan oleh banyaknya hadis palsu (tidak sahih) yang bertentangan dengan semangat egalitarianisme yang dibawa Nabi Muhammad Saw. Masalah hadis baru muncul setelah Nabi wafat, karena pada saat beliau masih hidup segala persoalan yang dialami kaum Muslim bisa langsung dikonsultasikan dengan beliau. Mernissi melacak persoalan itu jauh ke belakang, yakni pada saat Nabi wafat. Pertikaian mulai muncul di kalangan kaum Muslim dalam masalah kepemimpinan (khilafah). Hal ini menjadi pemicu utama ketegangan yang berlarut-larut antara para pemegang otoritas di kalangan kaum Muslim. Dalam analisisnya atas peristiwa yang terjadi pada masa itu, terutama yang berkaitan dengan pemilihan khalifah, Mernissi berkesimpulan bahwa suara kalangan elit, baik dari kalangan Anshar maupun Muhajirin lebih mendominasi, ${ }^{17}$ sehingga perundingan-perundingan yang terjadi lebih banyak terfokus pada hal-hal yang esensial menurut kalangan elit tersebut.

Sangat dimengerti seandainya setiap kelompok kepentingan yang ada memerlukan pembenaran dari nash suci. ${ }^{18}$ Semangat mencari pembenaran inilah yang menimbulkan dua tendensi yang antagonistik dalam penguraian hadis. Di satu pihak terdapat kecenderungan para politisi laki-laki untuk memanipulasi kesucian hadis, sementara di pihak lain terdapat ulama yang bersikeras menentang para politisi

17 Mernissi, Fatima dan Riffat Hassan.. Setara di Hadapan Allah. Alih bahasa oleh Tim LSPPA, Yogyakarta: LSPPA-Yayasan Prakarsa. Cet. I. 1996, hlm. 39

18 Mernissi, Fatima dan Riffat Hassan.. Setara di Hadapan Allah. Alih bahasa oleh Tim LSPPA, Yogyakarta: LSPPA-Yayasan Prakarsa. Cet. I. 1996, hlm. 43 
tersebut melalui penguraian fikih, dengan konsep-konsep, kaidahkaidah dan metode pengujiannya.

Mernissi menguraikan hadis-hadis misoginis yang terus diabaikan. Salah satu perawi yang mendapat sorotan tajam berkaitan dengan hal ini adalah Abu Hurairah, seorang perawi terkenal dari kalangan sahabat. Secara panjang lebar Mernissi menceritakan latar belakang kehidupan Abu Hurairah yang menyebabkannya antipati terhadap perempuan. Namun, yang sangat disayangkan Mernissi adalah mengapa alBukhari banyak memasukkan hadis misoginis yang diriwayatkan Abu Hurairah. Mernissi juga menjelaskan kritik Aisyah terhadap Abu Hurairah yang dinilainya dalam meriwayatkan hadis tersebut tidak mendengarkan ucapan Nabi secara Lengkap. Hadis ini, Menurut Aisyah, sebenarnya adalah ucapan Nabi yang sedang menggambarkan orang Yahudi mengenai tiga sebab yang menimbulkan bencana, yaitu rumah, perempuan, dan kuda. ${ }^{19}$

Dengan landasan pemikiran seperti di atas, Mernissi mengajak pembacanya untuk mengkaji kembali masalah-masalah yang berkaitan dengan perempuan, yang selama ini dianggap sudah selesai, termasuk masalah hijab. Dengan melihat asbāb al-nuzūl ayat hijab, Mernissi menyimpulkan bahwa sebenarnya hijab itu adalah pembatas antara dua laki-laki, yakni Nabi dan Anas Ibn Malik. Dari sini Mernissi kemudian membahas konsep ruang yang diterapkan Nabi. Mernissi juga menjelaskan sikap keras 'Umar Ibn alKhaththab kepada perempuan di samping kualitas 'Umar sendiri yang mengagumkan. ${ }^{20}$

Lebih lanjut Mernissi menyoroti kehidupan Nabi bersama isteri-isterinya dan kaum perempuan lainnya. Menurutnya, Nabi bersikap terbuka dan egaliter terhadap kaum perempuan. Yang mengherankan adalah mengapa sikap Nabi yang demikian itu kini terasa asing, bahkan aneh, bagi kebanyakan kaum Muslim setelah

19 Mernissi, Fatima dan Riffat Hassan.. Setara di Hadapan Allah. Alih bahasa oleh Tim LSPPA, Yogyakarta: LSPPA-Yayasan Prakarsa. Cet. I. 1996, hlm. 73

20 Mernissi, Fatima dan Riffat Hassan.. Setara di Hadapan Allah. Alih bahasa oleh Tim LSPPA, Yogyakarta: LSPPA-Yayasan Prakarsa. Cet. I. 1996, hlm. 130

202 Perkembangan Pemikiran dan Pergerakan Wanita.... 
beliau wafat. Mengakhiri pembahasannya dalam buku tersebut, Mernissi menampilkan Sukaynah, anak perempuan Husein Ibn Ali atau cucu Nabi, sebagai figur ideal perempuan Muslimah. ${ }^{21}$

Melalui tulisannya ini Mernissi menekankan bahwa apa yang dipahami umat Islam selama ini mengenai status perempuan dalam hadis Nabi sangat memengaruhi citra perempuan yang sebenarnya sangat tinggi. Image yang sudah mengakar di tengah masyarakat Muslim ini harus segera diubah dengan melakukan pendekatan sosiohistoris. Dia melakukan peninjauan terhadap sumber terjadinya kesalahpahaman persepsi tersebut. Ternyata sumber utama penyebab masalah ini adalah tersebarnya hadis "palsu" (tidak sahih) yang kemudian dijadikan sebagai sarana melegitimasi peran-peran kaum lelaki dalam rangka menancapkan superioritasnya. Dia mengajak umat Islam untuk lebih kritis lagi dalam memahami dan mengkaji hadis-hadis Nabi mengenai perempuan sehingga kaum perempuan dapat menempatkan diri pada posisi yang semestinya, baik dalam kehidupan keluarganya maupun dalam peran-peran lain di tengahtengah masyarakat.

Dalam artikel yang berjudul Can We Women Head a Muslim State? Mernissi mengemukakan perdebatan para ulama mengenai boleh tidaknya perempuan menjadi kepala pemerintahan. Satu pihak dari mereka mengatakan, perempuan boleh saja menjadi kepala negara, karena Islam telah memberi hak yang sama kepada perempuan dan laki-laki. Perempuan memiliki hak politik yang penuh dan dapat memimpin sebuah negara. Satu pihak yang lain mengatakan, perempuan tidak dapat menduduki jabatan kepala negara, karena ada hadis yang melarang perempuan untuk menduduki jabatan semacam itu. Setelah meneliti alasan-alasan dari kedua belah pihak yang bertentangan di atas, Mernissi melihat bahwa alasan pihak yang membolehkan perempuan menduduki jabatan kepala negara lebih bisa diterima, terutama alasan yang dikemukakan oleh Syeikh

21 Mernissi, Fatima dan Riffat Hassan.. Setara di Hadapan Allah. Alih bahasa oleh Tim LSPPA, Yogyakarta: LSPPA-Yayasan Prakarsa. Cet. I. 1996, hlm. 192-194 


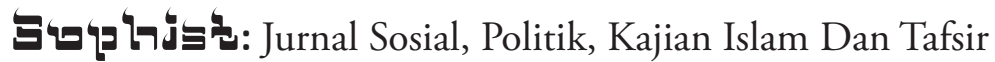

Muhammad al-Ghazali, seorang ulama dari Universitas Azhar Kairo (Mesir), sebagaimana yang dituangkan dalam bukunya al-Sunnat alNabawiyyat bain Abl al-Fiqh wa Abl al $\underline{\text { Hadis. }}{ }^{22}$

\section{Asghar Ali Engineer}

Asghar Ali Engineer dilahirkan di Rajasthan (dekat Udaipur, India) tahun 1939. Ia mendapatkan gelar doktor dalam bidang teknik sipil dari Vikram University (Ujjain, India). Pengetahuan agamanya diperoleh dari ayahnya yang Syi'ah. Ia adalah seorang aktivis Lembaga Swadaya Masyarakat (LSM/NGO) yang mempunyai perhatian besar terhadap tema-tema pembebasan dalam Al-Qur'an. Ia pernah menulis artikel yang berjudul "Toward a Liberation Theology in Islam" yang kemudian diterjemahkan ke dalam bahasa Indonesia "Islam dan pembebasan" (Yogyakarta: LSIK, 1993). Adapun bukunya yang berkaitan dengan masalah perempuan adalah The Rights of Women in Islam yang sudah diterjemahkan ke dalam bahasa Indonesia dengan judul Hak-Hak Perempuan dalam Islam (1994). Masih banyak karyanya yang lain yang menyuarakan keadilan dan pembebasan. ${ }^{23}$

Di awal tulisannya Asghar mengatakan, demi mengekalkan kekuasaan atas perempuan, masyarakat seringkali mengekang normanorma adil dan egaliter yang ada dalam al-Qur'an. ${ }^{24}$ Asghar juga mengatakan bahwa Al-Qur'an merupakan kitab suci pertama yang memberikan martabat kepada kaum perempuan sebagai manusia di saat mereka dilecehkan oleh peradaban besar seperti Bizantium dan Sassanid. Menurutnya, kitab suci ini memberikan banyak hak kepada perempuan dalam masalah perkawinan, perceraian, kekayaan, dan

22 Al-Ghazaliy, Syaikh Muhammad. Studi Kritis atas Hadis Nabi Saw.: Antara Pemahaman Tekstual dan Kontekstual. Alih bahasa oleh Muhammad Al-Baqir dari "AlSunnah al-Nabawiyyah baina Ahl al-Fiqh wa Ahl al-Hadits." Bandung: Penerbit Mizan. Cet. V. 1996, hlm. 65-68

23 Nuryanto, M. Agus. Islam, Teologi Pembebasan dan Kesetaraan Gender: Studi atas Pemikiran Asghar Ali Engineer. Yogyakarta: UII Press. Cet. I. 2001, hlm. 7-13

24 Engineer, Asghar Ali. Hak-hak Perempuan dalam Islam. Alih bahasa oleh Farid Wajidi dan Cici Farkha Assegaf dari “The Rights of Women in Islam.” Yogyakarta: Yayasan Bentang Budaya. Cet. I. 1994, hlm.1

204 Perkembangan Pemikiran dan Pergerakan Wanita.... 
warisan. $^{25}$

Berkaitan dengan perempuan, Asghar menganggap bahwa meskipun Al-Qur'an memuliakan perempuan setara dengan laki-laki, namun semangat itu ditundukkan oleh patriarkisme yang telah mendarah daging dalam kehidupan berbagai masyarakat, termasuk kaum Muslim. Meskipun secara normatif dapat diketahui bahwa Al-Qur'an memihak kepada kesetaraan status antara kedua jenis kelamin, secara kontekstual Al-Qur'an mengakui adanya kelebihan laki-laki di bidang tertentu dibanding perempuan. Namun, dengan mengabaikan konteksnya, fuqaha ' (jamak dari fāqih) berusaha memberikan status lebih unggul bagi laki-laki. ${ }^{26}$

Dari penjelasan di atas, tampaknya Asghar ingin mengatakan bahwa dalam khazanah tafsir, khususnya yang berkaitan dengan masalah perempuan, sebenarnya ada pendapat-pendapat yang bersikap empati atau pro-perempuan. Meskipun harus diakui, pendapat yang demikian kalah populer dibanding dengan pendapat-pendapat lain yang misoginis. Atas dasar empati inilah Asghar mencoba menunjukkan alternatif tafsiran atas beberapa ayat Al-Qur'an yang selama ini digunakan untuk mengekalkan subordinasi perempuan, yakni berkaitan dengan perceraian, perkawinan, hak waris, kesaksian, dan hak ekonomis. ${ }^{27}$

\section{Kesimpulan}

Itulah beberapa tokoh feminis Muslim yang banyak menyuarakan ide kesetaraan gender antara laki-laki dan perempuan. Tentu saja masih banyak tokoh feminis Muslim yang lain dengan ide-ide yang senada meskipun penuh dengan variasi. Ide-ide dan tulisan-tulisan

25 Nuryanto, M. Agus. Islam, Teologi Pembebasan dan Kesetaraan Gender: Studi atas Pemikiran Asghar Ali Engineer. Yogyakarta: UII Press. Cet. I. 2001, hlm. 61

26 Engineer, Asghar Ali. Hak-hak Perempuan dalam Islam. Alih bahasa oleh Farid Wajidi dan Cici Farkha Assegaf dari "The Rights of Women in Islam." Yogyakarta: Yayasan Bentang Budaya. Cet. I. 1994, hlm. 56

27 Engineer, Asghar Ali. Hak-hak Perempuan dalam Islam. Alih bahasa oleh Farid Wajidi dan Cici Farkha Assegaf dari "The Rights of Women in Islam.” Yogyakarta: Yayasan Bentang Budaya. Cet. I. 1994, hlm. 220 


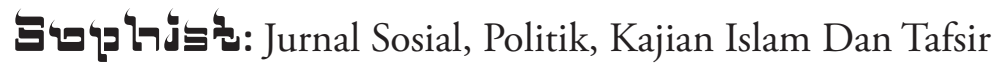

para tokoh itulah yang kemudian banyak memberi warna pemikiran para pemikir dan aktivis gerakan perempuan di dunia Islam (feminis Muslim) hingga sekarang ini, termasuk di Indonesia.

Di Indonesia mulai bermunculan para tokoh feminis yang terus menggelorakan kesetaraan dan keadilan gender yang mendapat dukungan dari pemerintah melalui kementrian pemberdayaan perempuan. Melalui kampus muncul pusat-pusat kajian wanita atau gender yang terus melakukan penelitian yang hasilnya disebarkan di masyarakat melalui diseminasi atau publikasi lewat media, baik elektronik maupun cetak. Usaha kaum feminis Indonesia ini tidak berjalan mulus begitu saja, tetapi juga mendapat berbagai tantangan, terutama dari para ulama salaf dan tradisional serta kaum fundamentalis yang memang sangat kuat image patriarkhinya.

206 Perkembangan Pemikiran dan Pergerakan Wanita.... 


\section{Daftar Pusataka}

Al-Ghazaliy, Syaikh Muhammad. (1996). Studi Kritis atas Hadis Nabi Saw.: Antara Pemahaman Tekstual dan Kontekstual. Alih bahasa oleh Muhammad Al-Baqir dari "Al-Sunnah alNabawiyyah baina Ahl al-Fiqh wa Ahl al-Hadits." Bandung: Penerbit Mizan. Cet. V.

Al-Hibri, Azizah. (2001). "Landasan Qur'ani Mengenai Hak-hak Perempuan Muslim pada Abad Ke-21", dalam Mohammad Atho Mudzhar dkk. (Ed.). Perempuan dalam Masyarakat Indonesia: Akses, Pemberdayaan dan Kesempatan. Yogyakarta: Sunan Kalijaga Press.

Al-Qardhawiy, Yusuf. (2003). Qardhawi Bicara Soal Perempuan. Alih bahasa oleh Tiar Anwar Bachtiar dari "Khuthāb wa Muhadlarat al-Qaradhawi 'an al-Mar'ah.” Bandung: Arasy. Cet. I.

Al-Qura'an al-Karim

Al-Siba'iy, Musthafa. (1984). Al-Mar'ah bain al-Fiqh wa al-Qanun. Beirut: Al-Maktab al-Islamiy. Cet. VI. Ilyas, Hamim. (2001). "Kontekstualisasi Hadis dalam Studi Gender dan Islam". Dalam Ema Marhumah dan Lathiful Khuluq (ed.). Rekonstruksi Metodologis Wacana Kesetaraan Gender dalam Islam. Yogyakarta: Pustaka Pelajar. Cet. I.

Amin, Qasim (1984). Tahrir al-Mar'ah. Kairo: Al-Markaz al'Arabiyyah li al-Bahtsi wa al-Nasyr.

(2003). Sejarah Penindasan Perempuan: Menggugat Islam Laki-laki, Menggurat Perempuan Baru. Alih bahasa Syariful Alam dari "The New Woman: A Document in the Early Debate of Egyptian Feminism.” Yogyakarta: Ircisod. Cet. I

El-Saadawi, Nawal. (2003). Wajah Telanjang Perempuan. Alih bahasa 


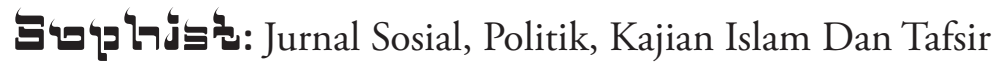

oleh Azhariah dari "Al-Wajhu al-Ari li al-Mar'ah al-Arabiyyah." Yogyakarta: Pustaka Pelajar. Cet. I.

Engineer, Asghar Ali. (1994). Hak-hak Perempuan dalam Islam. Alih bahasa oleh Farid Wajidi dan Cici Farkha Assegaf dari "The Rights of Women in Islam.” Yogyakarta: Yayasan Bentang Budaya. Cet. I.

Fudhaili, Ahmad. (2005). Perempuan di Lembaran Suci: Kritik atas Hadis-hadis Sahih. Yogyakarta: Pilar Religia. Cet. I.

Harahap, Rustam Dahar Karnadi Apallo. (2002). "Pola Emansipasi

Wanita di Mesir (Pemikiran Qasim Amin)". Dalam Sri Suhandjati Sukri (Ed.). Bias Jender dalam Pemahaman Isla., Yogyakarta: Gama Media. Cet. I.

Marhumah, Ema dan Lathiful Khuluq (ed.). (2001). Rekonstruksi Metodologis Wacana Kesetaraan Gender dalam Islam. Yogyakarta: Pustaka Pelajar. Cet.I.

Mernissi, Fatima. (1975). Beyond the Veil: Male-Female Dynamics in Modern Muslim Society, Newyork \& London: Schenkman Publishing Company.

Interpretation of Women's Rights in Islam. New York: Addison Wesley Publishing Company.

(1991b). Women and Islam: An Historical and Theological Enquiry, Oxford: Basil Blackwell.

Mernissi, Fatima dan Riffat Hassan. (1996). Setara di Hadapan Allah. Alih bahasa oleh Tim LSPPA, Yogyakarta: LSPPA-Yayasan Prakarsa. Cet. I.

Muhsin, Amina Wadud.(1993). Qur'an and Woman. Kuala Lumpur: Fajar Bakti SDN. BHD. Cet. I. (2006). Inside the Gender Jihad: Women's Reform in

208 Perkembangan Pemikiran dan Pergerakan Wanita.... 
Islam. (2006). Braintree, MA, USA: The Maple-Vail Book Manufacturing Group.

Mutahhari, Murteza. (1985). Perempuan dan Hak-haknya dalam Islam. Alih bahasa oleh M. Hashem dari "The Rights of Women in Islam". Bandung: Pustaka. Cet. I.

Nasution, Harun. (1991). Pembaharuan dalam Islam: Sejarah, Pemikiran, dan Gerakan. Jakarta: Bulan Bintang. Cet. VIII.

Nuryanto, M. Agus. (2001). Islam, Teologi Pembebasan dan Kesetaraan Gender: Studi atas Pemikiran Asghar Ali Engineer. Yogyakarta: UII Press. Cet. I.

Qutub, Muhammad. (1993). Setetes Parfum Wanita. Alih bahasa oleh Tajuddin dari "Qadliyyah Tahrir al-Mar'ah.” Jakarta: Pustaka Firdaus.

(2001). Islam Agama Pembebas. Alih bahasa oleh Fungky Kusnaedi Timur dari "Islam the Misunderstood Religion." Yogyakarta: Pustaka Pelajar. Cet. I.

Rahman, Fazlur. (1982). Islam and Modernity: Transformation of an Intelectual Tradition. Chicago: The University of Chicago Press.

Shalih, Su'ad Ibrahim. (2001). "Kedudukan Perempuan dalam Islam", dalam Mohammad Atho Mudzhar dkk. (Ed.). Perempuan dalam Masyarakat Indonesia: Akses, Pemberdayaan dan Kesempatan. Yogyakarta: Sunan Kalijaga Press.

Sukri, Sri Suhandjati (Ed.). (2002). Bias Jender dalam Pemahaman Islam. Yogyakarta: Gama Media. Cet. I. 